Resumen por el autor, Warren $\mathrm{H}$. Lewis

El endotelio en cultivo de tejidos

Los cultivos fueron hechos del modo corriente utilizando el medio Locke-Lewis. El hígado del embrión de pollo de siete dias consiste de higado y células endoteliales; cada uno de estos dos tipos emigra hacia el cubreobjetos de una manera característica. El endotelio forma un retículo laxo de células alargadas más o menos adherentes entre sí por medio de sus extremos y procesos. El carácter de este retículo varía considerablemente, pero los procesos celulares no son tan abundantes como en las células mesenquimatosas multipolares. En la periferia, y también en una forma de degeneración, las células pueden aislarse completamente unas de otras. Estos hechos indican que el retículo es adherente en vezde ser sincicial.

En los cultivos jóvenes las mitocondrias aparecen principalmente en forma de filamentos con un número variable de bastones y gránulos. A medida que envejecen dichos cultivos las mitocondrias tienden a disponerse radialmente a partir del centriolo y centrosfera en vías de crecimiento. También tienden a fragmentarse en bastones y gránulos. Su carácter y cantidad varían considerablemente. Gránulos y vacuolas que presentan una marcada afinidad con el rojo neutro (gránulos de degeneración) se acumulan gradualmente en las células y presentan una tendencia a amontonarse alrededor del centriolo y centrosfera dilatada. Las células binucleadas son comunes. En los cultivos más viejos, en los cuales los cambios degenerativos son evidentes, los núcleos a menudo se hacen irregulares y llenos de dentellones, dividiéndose en varios núcleos más pequeños El cctoplasma a veces presenta fibrillas longitudinales semejantes a las de las fibras musculares lisas depués de la fijación. Dichas fibrillas no pueden distinguirse en la célula viva.

Translation by José la. Nonidaz

Cornoll aredi al College, New Yorts 
AOTHOR'S ABSTRACT OF THIS PAPEH ISSUED BY THE BIBLIOGRAPHIC SERVICE, DECEMBET 27

\title{
ENDOTHELIUM IN TISSUE CULTURES
}

\author{
WARREN H. LEWIS \\ Carnegie Laboratory of Embryology, Johns Hopkins Medical School \\ FIVE PLATES (TWENTY-FOUR FIGURES) \\ INTRODUCTION
}

It is but natural that investigators in the field of tissue culture should have had and should still have more or less difficulty in identifying the various types of cells that grow out from explants of embryonic tissues. Most explants contain several types of cells that migrate out into the medium, some of which are comparatively easy to identify.

Nerve fibers from the central nervous system have been observed by Harrison ('07, '10), Ingebritsen ('13), and Levi ('16 a), and those from the sympathetic system by Lewis and Lewis ('12 a), and Matsumoto ('20). They are always quite characteristic. Endodermal membranes from the cells lining the alimentary tract and allantois were not at first identified as such (Lewis and Lewis, '11; Lambert, '12), but later their origin was established (Lewis and Lewis, ' $12 \mathrm{~b}$ ) and their recognition is now simple. Ectoderm from the skin (Lambert, '12) and the amnion (Lewis and Lewis, '12 b) grows out in the form of a membrane or sheet, as does also the pigmented epithelium from the retina (Luna, '17, fig. 1; Smith, '20). In the frog, likewise, the epithelial cells grow out as membranes (Uhlenhuth, '14, '15; Matsomoto, '18). Liver cells form membranes similar to the endoderm and are easily identified (Lynch, '21). The thyroid-gland cells grow out either as tubules or membranes (Carrel and Burrows, '11 a,' 11 b). Renal epithelium from the tubules likewise grows out in the form of membranes or sheets (Lewis and Lewis, '12 b) and sometimes as tubules (Reinhoff ${ }^{1}$ ). Blood-

${ }^{1}$ Unpublished. 
cells and wandering cells from the spleen (Foot, '12), bonemarrow (Erdmann, '17), lymph nodes (Lewis and Webster, '21 a, '21 b), and thymus (Pappenheimer, '13) seem always to migrate out as isolated cells and to remain so. Skeletal muscle has been observed by M. R. Lewis ('15, '19), and Lewis and Lewis ('17 a), and premuscle by Congdon ('15). This tissue is usually easy to recognize by its elongated multinuclear fibers and peculiar cytoplasm. Heart muscle has been studied by Burrows ('10, '12), Congdon ('15), and more especially by Levi ('16b, '19). Some of the figures of heart muscle shown by the lastnamed investigator correspond to our own unpublished ones, but this is not the case with those of Burrows and of Congdon, except possibly Congdon's figure 5. Smooth muscle resembles more the ordinary mesenchyme than either skeletal muscle or heart muscle and has been observed by Lewis and Lewis ('17 b) and by M. R. Lewis ('20 a).

We have been using in a rather loose fashion the terms mesenchyme, connective tissue, and fibroblast to designate the reticular radiating outgrowths in tissue cultures, because we were not sure of the exact identity of the tissue. I think most investigators working with tissue cultures have felt, as we do, that in using these terms they were probably dealing with several types of cells, namely, mesenchyme (including reticulum), fibroblasts, and other types of fixed connective-tissue cells, endothelium, and mesothelium. The literature is full of figures of these mesenchymal tissues, and among them are some which are probably endothelium. Most explants contain capillaries with endothelial cells and in many cultures these cells probably migrate out, although they may not be recognized as endothelium.

The present study is devoted to a consideration of the endothelial cells that migrate out from the explants of embryonic chick liver. It is well known that the liver, after ninety-six hours of incubation contains but two types of cells, the liver cells proper and the endothelium of the sinusoids (Minot, '00). It seemed to offer, therefore, an excellent opportunity for the study of endothelial outgrowths, as no difficulty should be encountered in distinguishing the liver-cell membrane from the loose 
reticular outgrowths (Lynch, '21). I have regarded these reticular outgrowths as endothelium. They differ in character from the reticular outgrowths of ordinary subcutaneous mesenchyme, as can be seen by comparing figures 1 and 2 of subcutaneous mesenchyme with figures 3 to 12 of endothelium.

\section{MATERIAL AND METHODS}

The explants were all from the livers of chick embryos of five to ten days' incubation. The cultures were made in the usual manner with Locke's solution $\left(\mathrm{NaCl}, 0.9\right.$ gram; $\mathrm{CaCl}_{2}, 0.024$ gram; $\mathrm{KCl}, 0.042$ gram; $\mathrm{NaHCO}_{3}, 0.02$ gram; dextrose, 0.5 gram, $\mathrm{H}_{2} \mathrm{O}, 100 \mathrm{cc}$.), $80 \mathrm{cc}$., plus chicken bouillon, 20 cc. The chicken bouillon was made according to the usual bacteriological method, except that freshly killed chicken was used in the place of beef. The hydrogen-ion concentration of the solutions varied from $\mathrm{pH} 6.4$ to $\mathrm{pH} 7.6$, but was usually about $\mathrm{pH} 6.8$ to $\mathrm{pH} 7.2$.

The figures are all from untouched photographs. The cultures from which they were taken were first subjected to a weak solution of janus green or neutral red, or the two in combination, until the mitochondria or the granules (and vacuoles) or both were stained. The cultures were than fixed with iodine vapor by placing a small flake of pure iodine on the bottom of the hollow-ground slide. The iodine vapor rapidly tinted the cells a beautiful yellow-brown. The mitochondria when stained with janus green became a very dark brown (almost black) and the neutral red granules became a dark red-brown. These colors are very advantageous for photography.

\section{GENERAL CHARACTERISTICS}

The endothelial cells migrate out from the liver explants onto the cover-glass in the form of a loose reticulum of elongated cells that are more or less adherent to one another by their extremities and processes. The character of this reticulum varies considerably in different cultures and in different regions of the same culture, as will be seen by comparing figures 3 to 12 . Near the explant and in the middle of the outgrowth the cells are elongated and slender, while at the periphery, where the crowding 
is less, they tend to flatten out in various directions. This is often still more marked in the isolated cells near the periphery. The explanation of this is probably not in a longitudinal polarity that disappears as the cells move peripheralward, but in the interplay of surface tension and of the differential adhesiveness of the cells for each other and for the cover-glass. The cells have apparently a greater adhesiveness for the cover-glass than for each other, and at the periphery, where they have more space, they are drawn out more and more on the cover-glass by the tension pull of the surface film of the fluid medium which lies against the cover-glass, until a balance between capillary attraction and cohesion is reached. Tait ('18) has recently described the spreading-out of certain blood-cells on glass as due to capillary attraction or, in other words, to surface-tension phenomena. The endothelial cells are evidently sticky and semifluid and are subject to the same physical forces as the blood-cells described by Tait. There may also be alterations, both local and general, in the consistency of the cytoplasm, which would favor the more extensive spreading-out of the cell. The consistency or viscosity of protoplasm is probably a variable character, as shown by Chambers ('17) and Seifriz ('20). The migration of the cells probably depends on alternating changes in the consistency of the protoplasm with changes in surface tension, as suggested by Loeb ('20, '21) for the amoeboid movements of the blood-cells of Limulus.

In the many cultures examined we have never seen spread-out endothelial cells from the liver with long, slender, fine-branched processes such as are shown in figures 1 and 2 from subcutaneous tissue. Figures 7 and 8 show the slender more elongated type of cell, and figures $3,4,9$, and 11 , the more common type, which possesses a broad, thin, lateral expansion. Figures 5 and 6, a more unusual variety, show the cells forming a somewhat membranous or sheet-like outgrowth resembling the mesothelium-like membranes in cultures from the heart and intestine. They are different, however, and mesothelial mombranes have not been observed in these liver cultures. 
The contrast between the endothelial cells and the liver cells is always quite marked, as shown in figures 5 and 12 . Sometimes the endothelial cells have exceedingly long and slender processes which extend out from the ends of the cells parallel to each other and to the long axes of the cells.

It is very difficult to determine whether the reticulum formed by the endothelial cells is a syncytium or not. In most places it is impossible to decide between actual fusion and mere adhesion. Occasionally it is clearly evident that the connections are only adhesions and that each cell preserves its individuality. This together with the fact that cells at the periphery readily become isolated from one another, would lead one to believe that actual continuity does not exist at any time. Again, under certain conditions, cells retract their processes and tend to round up, losing all connection with neighboring cells; this also would indicate adhesion and not fusion. The difficulty of determining the exact status of the exceedingly thin processes that extend out onto neighboring cells, especially where the cells are closely packed together, has led us in the past to consider that we were dealing with a syncytium, but we are inclined now to doubt this, both for endothelium and mesenchymal reticuli in general.

\section{CELL STRUCTURES}

Mitochondria. In young cultures the mitochondria are mostly in the form of threads of varying lengths and forms and often with no definite orientation. In addition there are often rods and granules (fig. 13). Sometimes, even on the first day, they may show a more or less radial arrangement about the centriole region. The conditions of the mitochondria in different cultures of the same age, and even in different cells of the same culture, vary so tremendously that it is difficult to give a general description of their appearance (figs. 13 to 20). No two cells are ever exactly alike. As the culture ages the mitochondria tend to become more or less radially arranged about the centriole and enlarging centrosphere (figs. 14, 15) and the threads tend to break up into rods and granules until finally the cells contain a large (giant) centrosphere and mitochondrial granules (figs. 
16, 19). The process is essentially the same as that already shown for fibroblasts and mesenchymal cells (W. H. Lewis, '19, '20).

I have before me seventy photographs (at 1450 diameters) of endothelial cells from this series, which were taken especially for the mitochondria, and it is difficult to select therefrom a few that will adequately convey to the reader an idea of the great variability displayed by these cells. In some cultures varying numbers of cells, as early as the third day, contained only granular mitochondria. This condition, however, may be delayed; some cells, even as late as the tenth day of cultivation, still showed thread-like, as well as granular and rod-shaped, mitochondria. Most of the cells, even up to the tenth day, contained all three types, granules, rods, and threads, varying in length thickness, and form. Variations in the amount of mitochondrial substance were sometimes quite marked. Presumably the mitochondrial complex is much more constant under the normal conditions within the embryo, and the great variations in the cultures are to be attributed to the variations in the abnormal conditions of the cultures. They do not appear to be due to differences in hydrogen-ion concentration from $\mathrm{pH} 6.4$ to $\mathrm{pH} 7.6$, nor to the age of the embryo, since great variations may occur in two successive cultures of the same series or even in the same culture. The most probable factor seems to be in the thickness of the medium drop and the accompanying evaporation in the air chamber, with consequent variations in the oxygen supply to the cells, dependent on the thickness of the fluid separating them from the air in the chamber of the hollow slide.

Granules and vacuoles. Granules and vacuoles, which have a marked affinity for neutral red, methylene blue, and brilliant cresyl blue, gradually accumulate in these cells and vary as much as they do in the fibroblasts and mesenchyme cells (Lewis and Lewis, '15; W. H. Lewis, '19, '20). The rate at which they make their appearance varies in different cultures; as do likewise the relative proportions and the size of the granules and vacuoles (figs. 21 to 23). We are still of the opinion that these granules and vacuoles bear a relation to degenerative changes 
going on within the cells (W. H. Lewis, '19). Recent work has tended to confirm this view. Mrs. Lewis ('20 b, '20 c) has shown that the addition of bacillus typhosus to the cultures causes a very rapid formation of similar vacuoles, and still more recently she has found that with the absence of dextrose from culture media vacuolization of the cells is more rapid and extensive than when dextrose is added. Miss Prigosen ('20, '21), working in our laboratory, found that the cells in film preparations of the subcutaneous tissue of chick embryos showed a rapid accumulation of granules and vacuoles that had a great affinity for neutral red.

Centriole and centrosphere. The centriole was not observed in the living cells, but in the fixed material could of ten be recognized near the nucleus as a small granule about which the mitochondria and neutral red granules tended to accumulate, the former often assuming a more or less radial arrangement. In older cultures there frequently develops about the centriole a centrosphere which gradually enlarges (figs. 14, 15, 16, 19, 20,21 ). This area varies in character; it may be quite homogeneous, as in figures 16, 19, 20, or granular, as in figures, 14, 15 . The enlargement of the centrosphere has not been followed in detail in these cells, but the process seems to be similar to that previously described for the mesenchyme cells (W. H. Lewis, '19, '20).

Nucleus. The nuclei are oval in form, long and narrow in the elongated cells, and short and plump in the spread-out flattened cells. The contour is usually smooth, but not infrequently in the older cultures it is uneven, being more or less irregular and indented. This appears to be the first indication of the process of budding and amitosis which results in the splitting of the nucleus into several, sometimes four or more, smaller nuclei (fig. 23). This process seems to take place only in the older cultures where other degenerative changes are evident. When a culture shows such changes there are usually many cells thus affected exhibiting various stages of the process. I have not actually followed this amitotic division in the living cells, but the evidence from the fixed material is very conclusive. In addition 
to this degenerative fragmentation of the nuclei, more normal binucleate cells are not uncommon in cultures of all ages.

Binucleate cells. Macklin (16) found that binucleate cells were more numerous in cultures from the hearts of chick embryos of five days' than in those of eight days' incubation and that they were more numerous in the two-day- than in the one-dayold cultures. He found, furthermore, that the average binucleate cell was approximately twice as large as the mononucleate, and that each nucleus was very similar in size, shape, and general appearance to the nuclei of the mononucleate cell-findings which my own observations have confirmed. I have further noted that there is a very decided increase in the mitochondrial content. Figure 10 shows a very large binucleate cell-a giant compared to its neighbors. Each nucleus seems to be as large as normal, while the cytoplasm is more than twice that of the largest mononuclear. The mitochondria are of the same general character (granules and rods) as those in the neighboring cells, but are almost, if not fully, fourfold in number.

Nucleolus. The nucleoli vary in number from one to four and also vary in position, size, and form. In some of the older cultures the nuclcoli are extruded from the nucleus, usually from one end (fig. 24). The exact details of this process have not as yet been carcfully followed. The nucleolus in some way reaches the end of the nucleus and lies against its membrane. Disintegration then takes place in this region, the nuclear membrane disappears, a vacuole-like area develops in the adjoining cytoplasm, and the nucleolus eventually comes to lie within it.

Cytoplasm. In the living cultures both ectoplasm and endoplasm appeared homogeneous. In the fixed material the ectoplasm was sometimes homogeneous and sometimes striated (figs. 16 and 17). These striae were not seen in the living cells, but formed as the cytoplasm coagulated under the influence of the iodine vapors. I do not believe they correspond to preformed structures. They varied in size and ran out into processes often to their very tips. This would seem to indicate that the peculiarity of the ectoplasm which causes it to coagulate into fibrillae is a molecular thing associated with tension, due to the 
surface tension pull. This striation was similar to, but not so marked as that seen in the smooth-muscle cells in cultures, and it suggests that there is an unusual amount of contractile substance in endothelium which is interesting in connection with recent physiological work on the contraction of capillaries by Dale, Krogh, and Hooker.

The endoplasm became very finely granular on coagulation and in it were embedded most of the mitochondria and granules.

\section{BIBLIOGRAPHY}

Burrows, M. T. 1910 'The cultivation of tissues of the chick embryo outside the body. J. Am. M. Ass., vol. 55.

1911 The growth of tissues of the chick embryo outside the animal body, with special reference to the nervous system. Jour. Exp. Zoöl., vol. 10.

1912 Rhythmische Fontraktionen der isolierten Herzmuskelzelle ausserhalb des Organismus. München. med. Wochnschr., No. 27.

Carrel, A., AND M. T. Burrows 1911 a Cultivation of tissues in vitro and its technique. J. Exper. Med., vol. 13.

$1911 \mathrm{~b}$ Cultivation in vitro of thyroid gland. J. Exper. Med., vol. 13.

Chambers, R. 1917 Microdissection studies. II. The cell aster: a reversible gelation phenomenon. Jour. Exp. Zoöl., vol. 23, pp. 483-504.

Covgdon, E. D. 1915 The identification of tissues in artificial cultures. Anat. Rec., vol. 9.

ERdmann, RHoda 1917 Cytological observations on the behavior of chicken bone-marrow in plasma medium. Am. Jour. Anat., vol. 22.

Foot, N. 1912 Ueber das Wachstum von Knochenmark in vitro, etc. Beitr.z. path. Anat., Bd. 53.

Harrison, R. G. 1907 Observations on the living developing nerve fiber. Anat. Rec., vol. 1.

1910 The outgrowth of the nerve fiber as a mode of protoplasmic movement. Jour. Exp. Zoöl., vol. 9.

INGEBRITSEN, R. 1913 Studies on the degeneration and regeneration of axis cylinders in vitro. J. Exper. Med., vol. 17.

LAMBERT, R. A. 1912 Variations in the character of growth in tissue cultures. Anat. Rec., vol. 6.

Levi, G. 1916 a Sull' origine delle reti nervose nelle colture di tessuti. Rend. d. R. Accademia dei Lincei, vol. 25.

1916 b Migrazione di elementi specifici differenziati in colture di miocardio e di muscoli scheletrici. Arch. per le Sci. Med., vol. 40.

1917 Connessioni e struttura degli elementi nervosi R. Accademia dei Lincei.

1919 Nuovi studi su cellule coltivate 'in vitro.' Arch. ital, di Anat. e di Emb., vol. 16. 
LewIS AND LEWIS 1911 The cultivation of tissues from chick embryos in solutions of $\mathrm{NaCl}, \mathrm{CaCl}_{2}, \mathrm{KCl}$, and $\mathrm{NaHCO}_{3}$. Anat. Rec., vol. 5 . 1912 a The cultivation of sympathetic nerves from the intestine of chick embryos in saline solutions. Anat. Rec., vol. 6 .

1912 b Membrane formations from tissues transplanted in to artificial media. Anat. Rec., vol. 6.

1915 Mitochondria (and other cytoplasmic structures) in tissue cultures. Am. Jour. Anat., vol. 17.

LEWIs, M. R. 1915 Rhythmical contraction of the skeletal muscle tissue observed in tissue cultures. Am. J. Physiol, vol. 38.

1916 Sea water as a medium for tissue cultures. Anat. Rec., vol. 10.

LEWIS AND LEWIS 1917 a Behavior of cross-striated muscle in tissue cultures. Am. Jour. Anat., vol. 22.

$1917 \mathrm{~b}$ The contraction of smooth muscle cells in tissue cultures. Am. J. Physiol., vol. 44.

Lewrs, W. H. 1919 Degeneration granules and vacuoles in the fibroblasts of chick embryos cultivated in vitro. Johns Hopkins Hosp. Bull., vol. 30 .

LEWIS, W. H. 1920 Giant centrospheres in degenerating mesenchyme cells of tissue cultures. J. Exper. Med., vol. 31.

Lewis, M. R. 1920 Muscular contraction in tissue cultures. Contributions to Embryology, vol. 9. Carnegie Inst. of Wash., Pub. 272.

1920 a The rapid formation of vacuoles due to the presence of bacillus typhosus in the cells of tissue cultures. Anat. Rec., vol. 18.

$1920 \mathrm{~b}$ The formation of vacuoles due to bacillus typhosus in the cells of tissue cultures of the intestine of the chick embryo. J. Exper. Med., vol. 31.

1921 The formation of vacuoles in the cells of tissue cultures owing to the lack of dextrose in the media. Anat. Rec., vol. 20.

Lewis, W. H., ANd L. T. Werster 1921 a Migration of lymphocytes in plasma cultures of human lymph nodes. J. Exper. Med., vol. 33.

$1921 \mathrm{~b}$ Giant cells in cultures from human lymph nodes. J. Exper. Med., vol. 33 .

LoEb, Leo 1920 The movements of the amocbocytes and the experimental production of amoebocyte (cell-fibrin) tissuc. Washington Univ. Studies, vol. 8; Seientific Series, no. 1, pp. 3-79.

1921 Amoeboid movement, tissue formation and the consistency of protoplasm. Science, N. S., vol. 53, p. 261.

Luna, E. 1917 Note citologiche sull' epitelio pigmentato della retina coltivato "in vitro." Arch. ital. di Anat. e di Emb., vol. 15.

LYNCH, R. S. 1921 The cultivation in vitro of liver cells from the chick embryo. Amer. Jour. Anat., Vol. 29, p. 281.

Macklin, C. C. 1916 Binucleate eclls in tissue cultures. Contributions to Embryology, Carnegie Inst. of Wash., Pub. 224.

Matsumoto, S. 1918 Contribution to the study of epithelial movement. The corneal epithelium of the frog in tissue culture. Jour. Exp. Zö̈l., vol. 26. 
Matsumoto, T. 1920 The granules, vacuoles and mitochondria in the sympathetic nerve fibers cultivated in vitro. Johns Hopkins Hosp. Bull., vol. 31 .

Minot, C. S. 1900 On a hitherto unrecognized form of blood circulation without capillaries in the organs of vertebrata. Proc. Boston Soc. Nat. Hist., vol. 29.

Pappenheimer, A. M. 1913 Further studies of the histology of the thymus. Am. Jour. Anat., vol. 14.

Prigosen, R. E. 1920 Vacuoles formed in certain cells studied under abnormal conditions. Anat. Rec., vol. 18.

1921 The formation of vacuoles in connective tissue cells due to abnormal conditions. Johns Hopkins Hosp. Bull., vol. 32.

Seifriz, W. 1920 Viscosity values of protoplasm as determined by microdissection. Bot. Gazette, vol. 70.

Smith, D. T. 1920 The pigmented epithelium of the embryo chick's eye studied in vivo and in vitro. Johns Hopkins Hosp. Bull., vol. 31.

TAIT, JohN 1918 Capillary phenomena observed in blood cells, thigmocytes, phagocytosis, amoeboid movement, differential adhesiveness of corpuscles, emigration of leucocytes. Quart. J. Exper. Physiol., vol. 12.

Uhlentuth, E. 1914 Cultivation of the skin epithelium of the adult frog, Rana pipens. J. Exper. Med., vol. 20.

1915 The form of the epithelial cells in cultures of frog skin, and its relation to the consistency of the medium. J. Exper. Med., vol. 22. 


\section{PLATE 1}

EXILANATION OF FIGURES

1 Culture 708. Subcutaneous tissue, 8-day chick embryo; 2-day culture; $\mathrm{pH} 7.6$; janus green, iodine. $\times 146$.

2 Same culture. $\times 480$.

3 Culture 667. Endothelium from liver, 7-day chick embryo; 3-day culture; janus green, iodine. $\times 146$.

4 Same culture. $\times 480$.

5 Culture 666. Endothelium from liver, 5-day chick embryo; 4-day culture; $\mathrm{pH} 6.5$; janus green, iodine. $\times 146$.

6 Same culture. $\times 480$. 


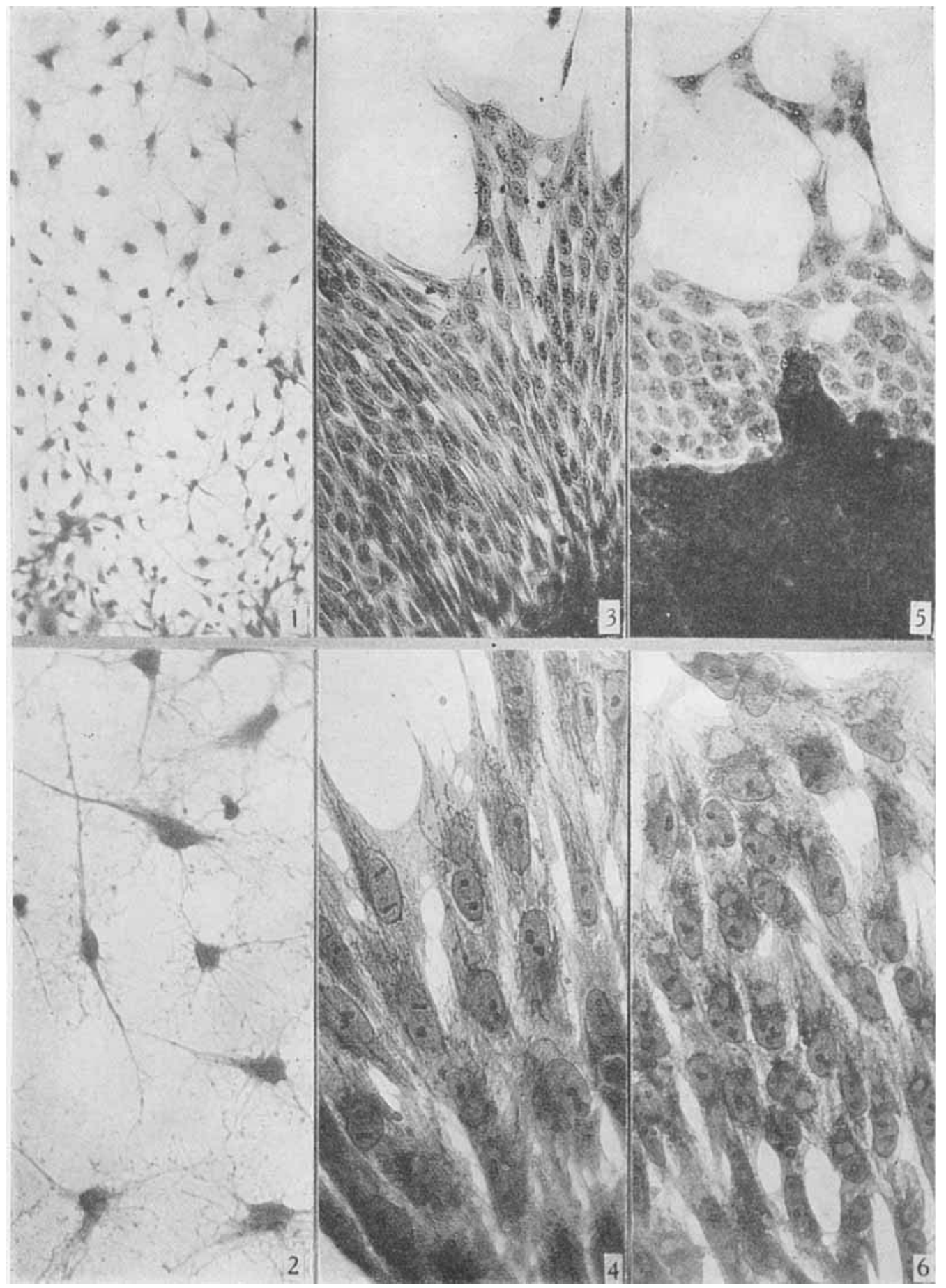




\section{PLATE 2}

\section{EXPLANATION OF FIGURES}

7 Culture 681. Endothelium from liver, 8-day chick embryo; 7-day culture; janus green, iodine. $\times 146$.

8 Same culture. $\times 480$.

9 Culture 636. Endothelium from liver, 10-day chick embryo; 1-day culture; janus green, neutral red, iodine. $\times 480$.

10 Culture 678. Endothelium from liver, 8-day chick cmbryo; 4-day eulture; janus green, iodine. $\times 480$.

11 Culture 717. Endothelium from liver, 8-day chick embryo; 6-day culture; $\mathrm{pII} 7.4$; janus green, iodine. $\times 480$.

12 Culture 683. Endothelium and liver cells from liver, 8-day chick embryo; 6 -day culture; $\mathrm{pH} 6.4$; janus green, neutral red, iodine. $\times 480$. 


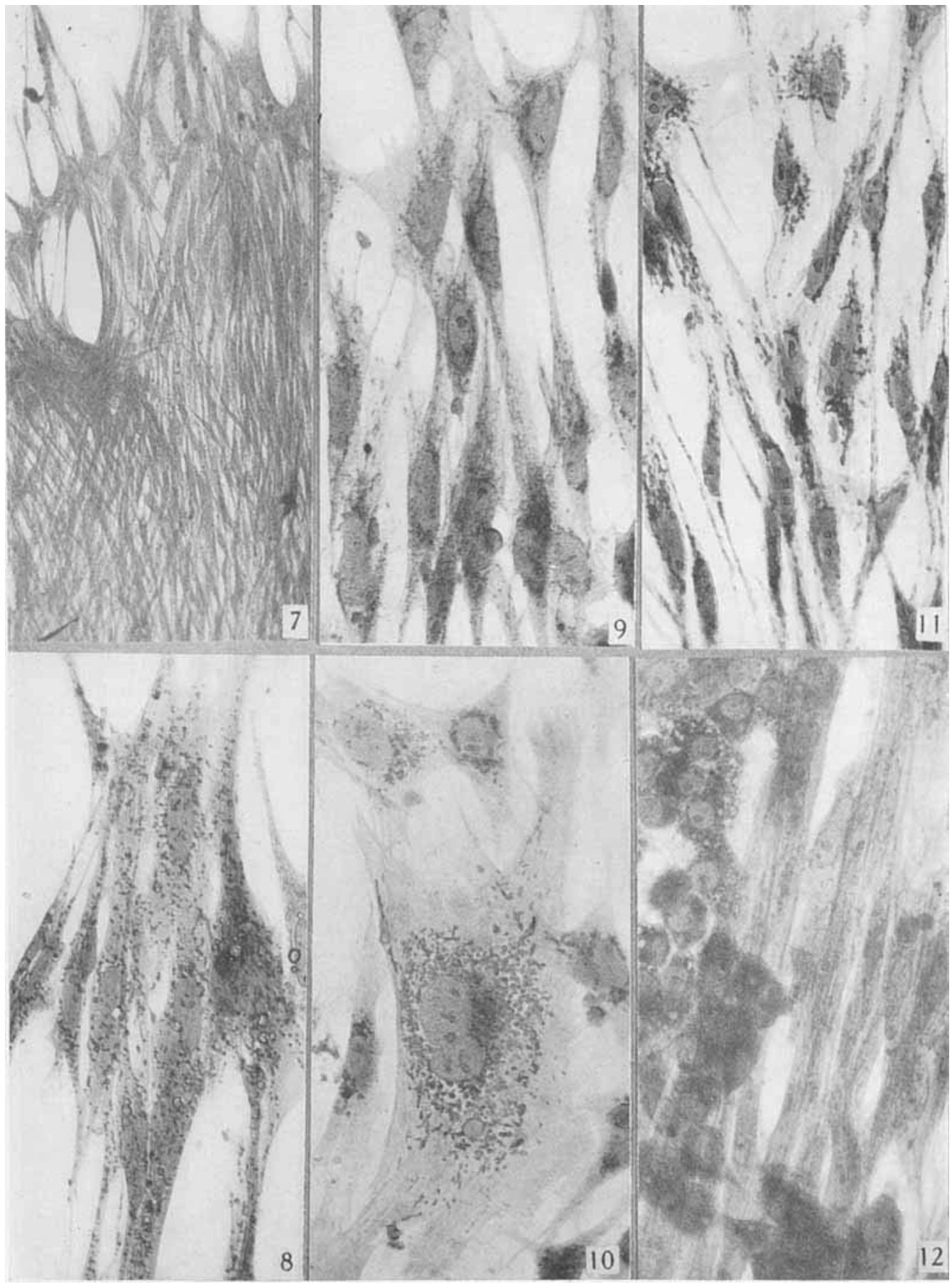




\section{PLA'TE 3}

EXPLANATION OF FIGURES

13 Culture 636 (same culture as fig. 9). Endothclial cell from mid part of outgrowth. Iiver, 10-day chick embryo. 1-day culture. Mitochondria, threads, rods, granules; few neutral red granules. Janus green, neutral red, iodine. $\times 1450$.

14 and 15 Culture 717 (same culture as fig. 11). Endothelial cells from liver, 8-day chick embryo; 6-day culture; pH 7.4 Variations in shape of cells and arrangement of mitochondria. Janus green, iodine. $\times 1450$. 
WARREN HI. LEWIS
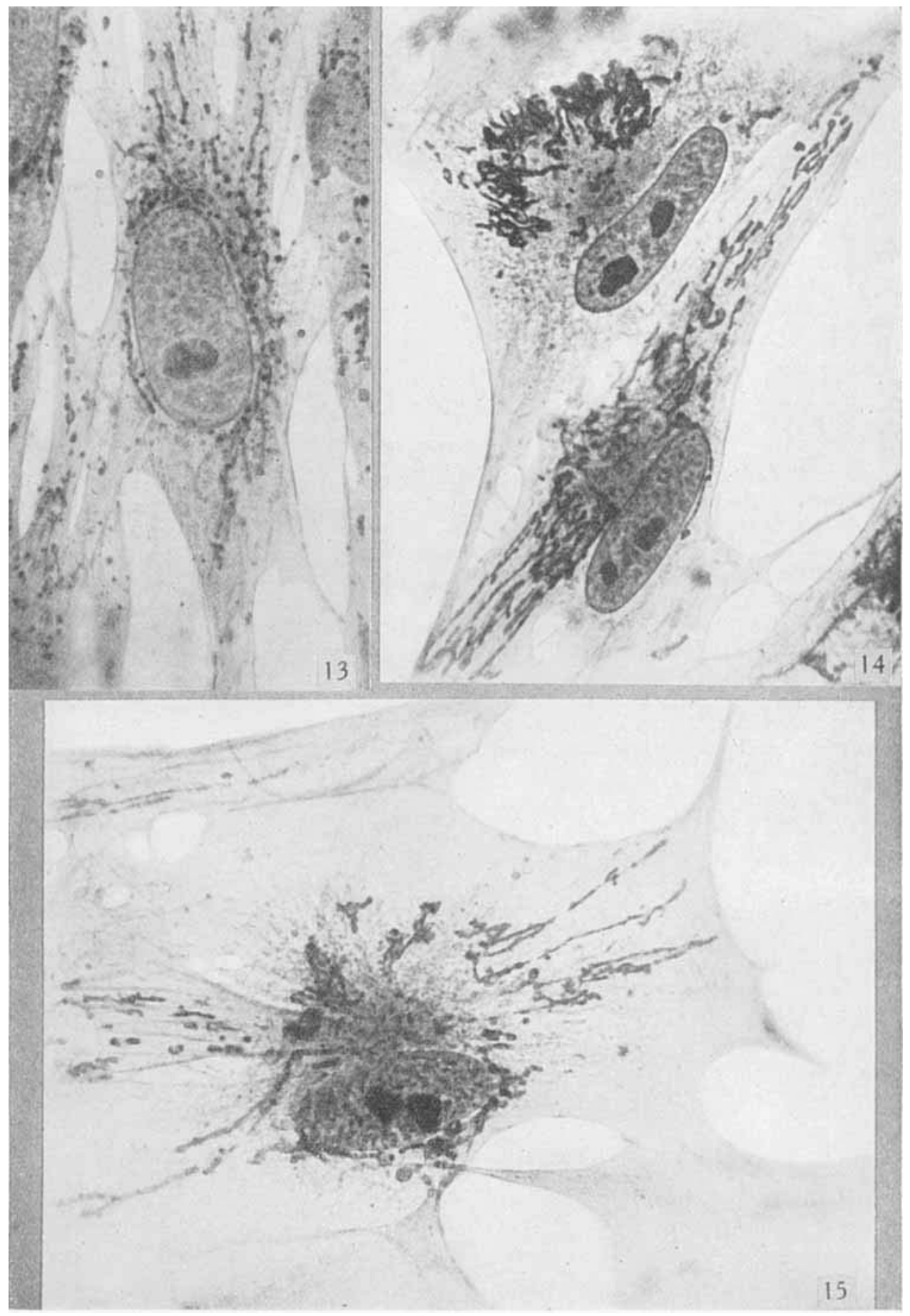


\section{PLATE 4}

\section{EXPLANATION OF FIGURES}

16 Culture 613. Endothelial cell from liver, 7-day chick embryo; 5-day culture. Mitochondrial vesicles, degeneration vacuoles, large centrosphere, eytoplasmic striae. Janus green, neutral red, iodine. $\times 1450$.

17 Culture 612. Endothelial cell from liver, 9-day chick embryo; 3-day culture. Marked striation of cytoplasm. Janus green, neutral red, iodine. $\times 1030$.

18 Culture 716. Endothelial cell from liver, 8-day chick embryo; 6-day culture; pH 7.4. Branching mitochondria. Janus green, iodine. $\times 1450$.

19 and 20 Culture 666 (same culture as figs. 5 and 6). Endothelial cells from liver, 5-day chick embryo; 4-day culture. Fig. 19, mitochondrial granules and vesicles, large centrosphere. Fig. 20, mitochondrial threads, rods, granules, large centrosphere. Janus green, iodine. $\times 1450$. 

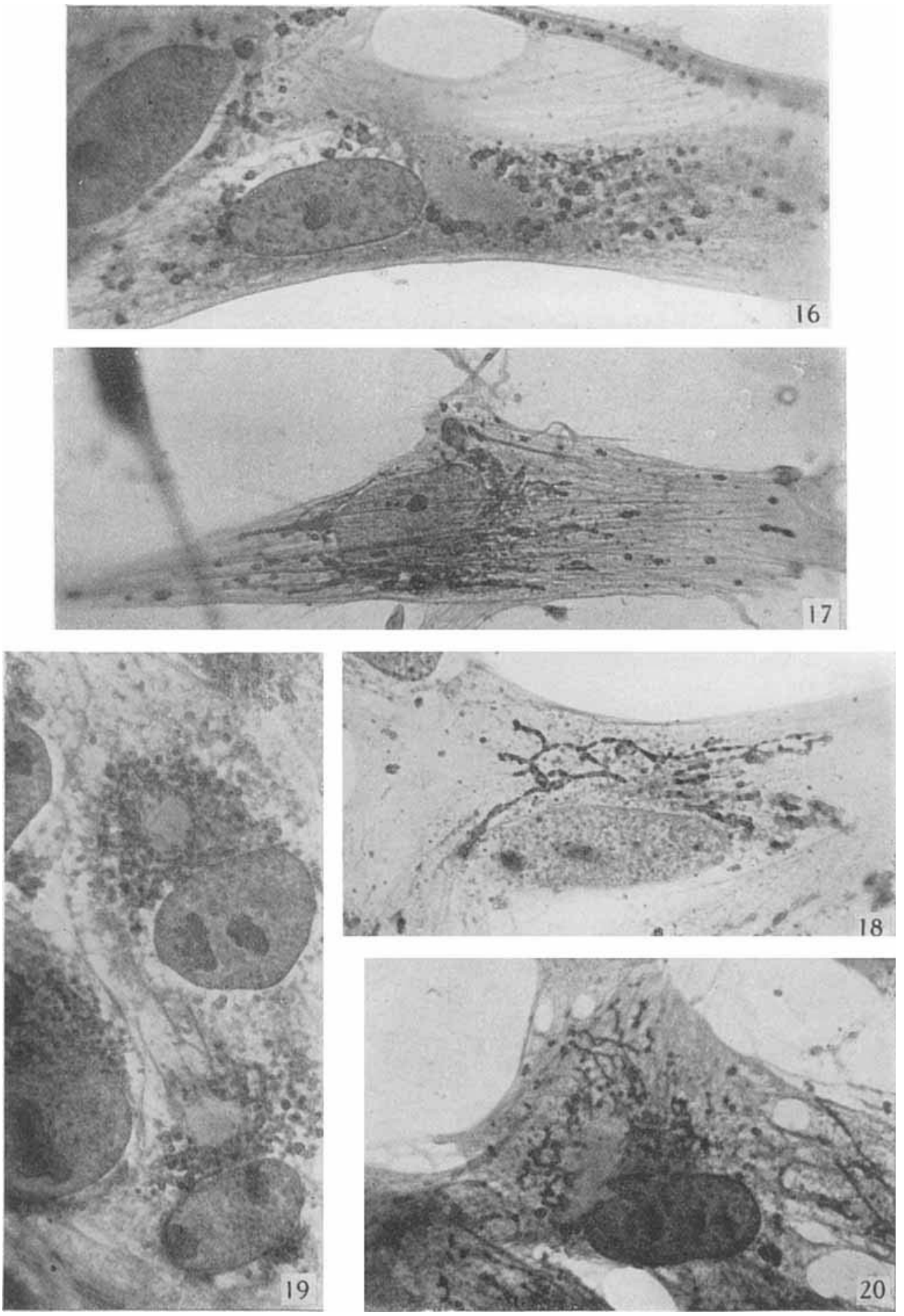


\section{PLATE 5}

\section{RXPLANATION OF FIGURES}

21 Culture 675. Endothelial cells from liver, 7-day chick embryo; 7-day culture. Numerous large degeneration vacuoles, mitochondrial granules, large centrosphere Janus green, iodine. $\times 480$.

22 Culture 694. Endothelial cells from liver, 7-day chick embryo; 7-day culture. Large vacuoles (dark in figure), pale long mitochondria. Janus green, neutral red, iodine. $\times 1450$.

23 and 24 Culture 676. Endothelial cells from liver, 6-day chick embryo; 10-day culture; pH 6.6. Fig. 23, fragmentation of nucleus, vacuoles, mitochondrial threads, rods, granules. Fig. 24, extrusion of nucleolus. Janus green, iodine. $\times 1450$. 

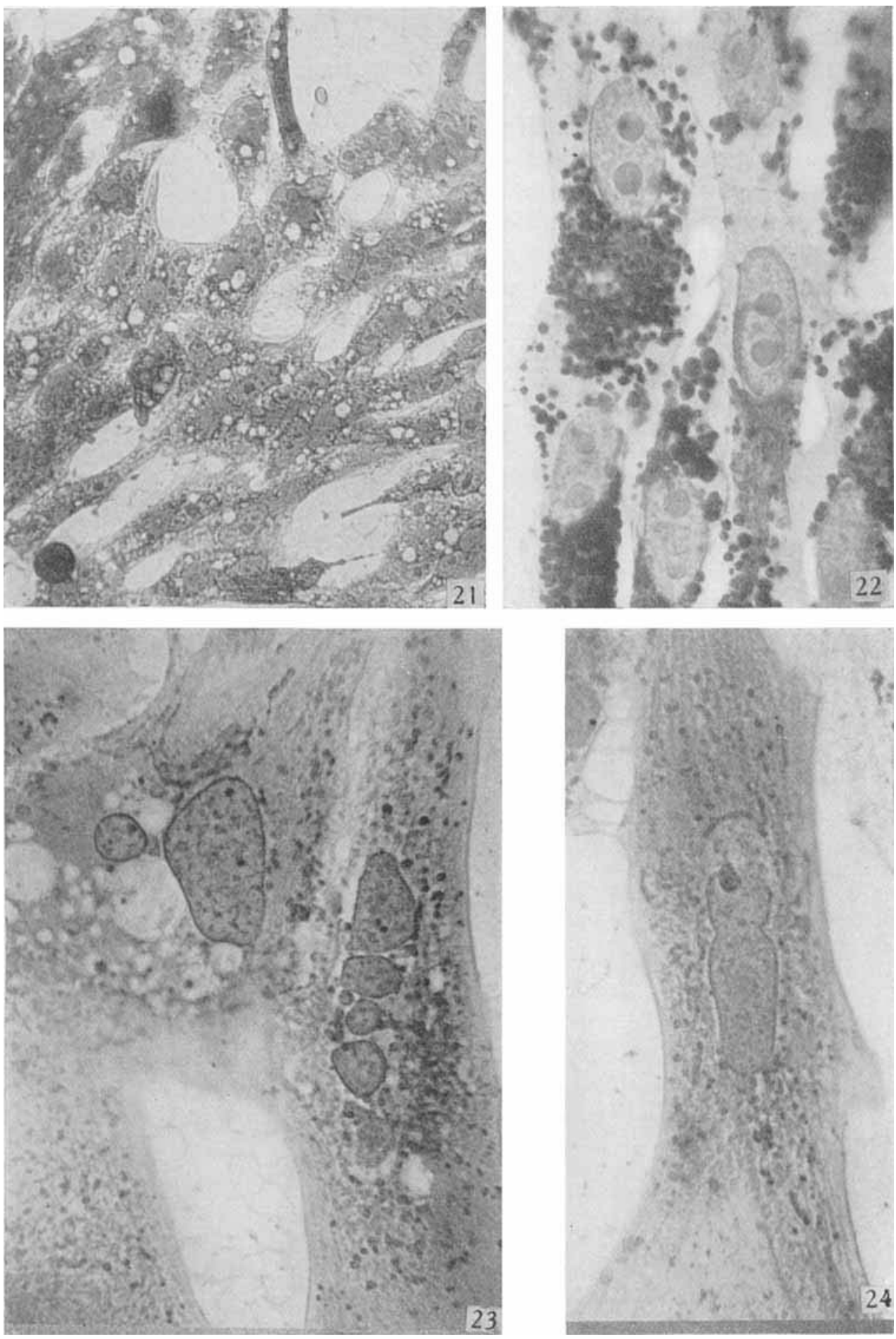